УДК $346.3 ; 347.4$

DOI https://doi.org/10.32837/pyuv.v0i2(31).563

\author{
О. Ю. Піддубний \\ orcid.org/0000-0003-4867-4613 \\ доктор юридичних наук, доиент, \\ завідувач кафедри иивільного та господарського права \\ Національного університету біоресурсів і природокористування
}

\title{
ДО ПИТАННЯ ПРО РОЗМЕЖУВАННЯ ЦИВІЛЬНИХ І ГОСПОДАРСЬКИХ ДОГОВОРІВ І ЙОГО ВПЛИВ НА ІНШІ ВИДИ ДОГОВОРІВ
}

Постановка проблеми. Договір як загальний і понадгалузевий інструмент узгодження суспільної діяльності широко й активно використовується різними правовими галузями, а від визначення галузевої належності конкретних договорів залежать юридичні наслідки їх укладення, способи захисту прав сторін. Базуючись на нормах цивільного права, договори, тим не менше, є суттєво неоднорідними.

На це звертали увагу науковці О. Беляневич, С. Бервено, Н. Кузнєцова, О.Дзера, Р. Стефанчук В. Мамутов, О. Старцева, В. Щербина та багато інших.

Мета статті полягає у зіставленні цивільного і господарсько-правового договору й уточненні деяких критеріїв їх розмежування.

Виклад основного матеріалу дослідження. Економічні відносини вимагають від права, а конкретніше - від договірного права більш гнучкого застосування нових непойменованих, змішаних договорів і вдосконалення наявних договірних конструкцій $[1$, с. 43$]$. У питанні розмежування цивільних і гоподарських договорів автор дотримується думки, так само, як частина сучасних представників господарського права, що господарській договір є різновидом цивільно-правової угоди, тобто за своєю природою є погодженою дією двох або більше сторін, спрямованою на набуття, зміну або припинення цивільних прав та обов'язків [2, с. 21].

Всі майнові відносини, організовані на договірних засадах, умовно можна розділити на три основні групи, які становлять відповідні договори.

Ординарні (прості) цивільно-правові договори - договори фізичних осіб між собою або з юридичними особами, укладені для особистих потреб, що не характеризуються як споживчі (правильніше було б назвати споживацькими договори, в яких стороною є споживач, щоб відмежувати їх від термінологічно усталених відносин споживчої кооперації, але задля уникнення негативних конотацій, які несе в собі прикметник «споживацький», назвемо їх споживчими). Наприклад, ординарним є договір придбання житла у власність у інших фізичних осіб, або коли фізична особа дає приватні уроки на оплатній основі та використовує їх як засіб існування, або якщо автор літера- турного твору укладає з видавництвом договір на право публікації його твору й отримує авторський гонорар.

Такі договори характеризує задоволення особистої життєвої потреби хоча б у однієї сторони та іï нестандартизований або несистематичний характер. Їх укладання регулюється нормами Цивільного кодексу України [3]. Обсяг прав і обов'язків сторін такого договору є рівним.

В основу цього виду договорів пропонуємо покласти задоволення потреби в індивідуалізованому товарі або послузі (якщо сторони є приватними особами) або реалізацію чи придбання виробів, напівфабрикатів, різних заготовок, об'єктів права інтелектуальної власності суб'єктами господарювання у приватних осіб або як індивідуалізованих об’єктів (інтелектуальної власності, майна, що було у вжитку), або як стандартизованих (закупівля молока, грибів, ягід, лікарських рослин), що вимірюються родовими ознаками та кількісними характеристиками, але які реалізуються на непрофесійній основі. У такому вигляді ми маємо справу з «чистим» цивільно-правовим договором, що не регулюється нормами інших галузей. Звичайно, господарська діяльність суб'єкта господарювання - сторони договору підпорядкована різним спеціальним правилам, але вони не мають значення для сторони - приватної особи.

Споживчі цивільно-правові договори укладаються між споживачем і продавцем (виконавцем), котрий є суб'єктом господарювання, що оперує на ринку стандартизованих товарів і послуг, про якість, терміни, ціну та інші умови, за яких реалізується продукція.

Ці договори мають виражений публічний характер, що передбачає пропозицію про придбання товару чи послуги невизначеному колу суб'єктів для задоволення їхніх особистих потреб на єдиних умовах для визначених категорій споживачів. Для їх регулювання використовується як Цивільний, так і Господарський кодекси та інші законодавчі акти. Принаймні, так стверджує спеціальний закон [4] - встановлюючи у ч. 1 ст. 2, що законодавство про захист прав споживачів складається і з Господарського кодексу України. Водночас закон загальний, яким є сам Господарський кодекс України, в ч. 3 ст. 175 заперечує можли- 
вість віднесення будь-яких зобов'язань, стороною в яких є громадянин (ще однин невдалий термін), до господарських [5]. Але ми однозначно на боці Господарського кодексу, оскільки в контексті віднесення тих чи інших відносин до господарських характер спеціального закону має саме цей законодавчий акт.

Для прикладу. Придбання того ж житла, але не у фізичної особи - власника, а у забудовника багатоквартирного будинку, котрий пропонує такі квартири для придбання, є споживчим договором. Придбання фізичною особою автомобіля, що був у вжитку, у юридичної особи є ординарним договором, а придбання нового автомобілю у дилера - споживчим.

Якщо репетитор реєструється як фізична особа - підприємець (суб’єкт господарювання), бажаючи здійснювати освітні послуги на професійній основі, його уроки стають послугою для споживачів і будуть об'єктом споживацького договору.

Особливістю таких договорів є надання законодавцем численних переваг у правах споживачу і покладення відповідних обов'язків щодо їх забезпечення на виробника (виконавця). Це робиться 3 метою захисту споживача, який не може і не повинен розбиратися в усіх особливостях того чи іншого товару чи послуги та через свою необізнаність не повинен ставати об'єктом маніпуляції з боку виробника (виконавця). Так менший обсяг можливостей і компетентності споживача компенсується більшим обсягом прав.

Попри норму про подвійне підпорядкування обом кодексам, нам у такому виді договорів вбачається лише цивільно-правове регулювання. Його цілком достатньо, оскільки споживач завжди в цих відносинах перебуває у своєму цивільному праві, і те, що договір є публічним, обмежує лише продавця, споживача ж лише управнює стосовно того, використовувати це правило аби укласти договір чи не використовувати, якщо пропозиція виробника його не влаштовує. Та і взагалі, цивільне право має у своєму арсеналі низку обмежень договірної свободи, із яких публічність договору - не виняткове і не єдине, є ще договір про приєднання, попередній договір, договір з особою, котра виграла прилюдні (електронні) торги; також називаються типовий договір і договір за державним замовленням [6, с. 142], хоча останні обмеження, на нашу думку, вже явно належать до господарсько-правового інструментарію.

Звичайно, є певні правила, що стандартизують товари, ставлять вимоги щодо їх безпечності та якості, але такі самі показники якості можуть застосовуватися і в договорах між приватними особами - наприклад, правила про агрохімічну паспортизацію при оренді земельних ділянок. А це показник, що наявність спеціальних правил щодо об'єкта договору не робить договір господарським.
Із боку цивільного права «значення предмета договору полягає у визначенні не лише кола майнових об'єктів, але і закономірностей діяльності суб’єктів права із приводу цих об'єктів» [7, с. 185].

Згідно із пропонованою класифікацією господарський договір має місце там, де його сторони мають на меті господарську діяльність. Корені такого підходу, як справедливо зазначено в літературі, сягають періоду до незалежності України, поставивши під сумнів універсальність і самодостатність цивільного договору як єдиного інструменту врегулювання майнових відносин [8, с. 72].

Розглянемо це положення детальніше на прикладі того, що пропонується вважати «чистими» господарськими договорами.

Господарські договори - це договори між суб'єктами господарювання щодо забезпечення їхньої господарської діяльності, які є третім видом договірних відносин. Такі відносини регулюються нормами Господарського і Цивільного кодексу, численними актами законодавства у відповідних сферах - промисловості, енергетики, фінансів, сільського господарства тощо. Сторони цих договорів є професійними учасниками відповідних ринків, зареєстрованими у встановленому порядку. Права їхніх учасників захищаються окремим спеціалізованим судом - господарським - i на однакових, достатньо суворих засадах, оскільки професійні учасники господарських відносин не можуть посилатися на складність і специфічність законодавства, багатовимірність і ризикованість самої діяльності та вимагати до себе на цій підставі особливого ставлення з боку законодавця i суду, адже, приймаючи для себе рішення про зайняття такою діяльністю, вони заздалегідь акцептують і всі пов'язані з її здійсненням ризики. Господарський договір, як зазначається, завжди укладається із господарською (комерційною) метою для досягнення необхідних сторонам господарських і комерційних результатів. Суб'єктами майново-господарських зобов'язань, відповідно, є суб'єкти господарювання і негосподарюючі суб'єкти - юридичні особи [9, с. 145] при здійсненні господарської діяльності [10, с. 117]. Крім того, він поєднує майнові й організаційні елементи, наявні та необхідні до врахування публічні інтереси [11, с. 45], хоча ці два критерії дещо абстрактні, з огляду на те, що і не господарський договір може укладатися з організованим суб'єктом, і цивільний договір, навпаки, не може укладатися 3 метою, яка суперечить інтересам держави і суспільства, а отже, враховує публічний інтерес.

Тобто для віднесення договорів до господарських є основний критерій - змістовний і додатковий - суб'єктний, що верифікує безпомилкове віднесення певного договору до числа господарських.

Висновки. Майнові відносини опосередковуються трьома видами договорів - ординарним, 
споживчим і господарським, які поділяються за критеріями мети, сторін і предмету. Ці критерії $€$ нерозривними, тому що статус суб'єкта договірних відносин $є$ визначальним для мети договору.

Так, суб’єкт, якого створено для господарської діяльності, має на меті тільки господарську діяльність. Водночас мета приватної особи щодо задоволення своїх потреб дозволяє класифікувати тип договору тільки у зв'язці із суб'єктом, котрий знаходиться на «протилежному кінці». Ящо там теж приватна особа, договір є ординарним. Якщо там господарюючий суб'єкт - договір може бути або ординарним, якщо предмет не є стандартизованим товаром або послугою, або споживчим, якщо навпаки.

Потенційно вцей же ряд можна додати трудовий договір, оскільки при застосуванні всіх перерахованих критеріїв буде виявлятися його специфіка.

Не вбудуються в цей ряд колективні трудові договори, оскільки не є майновими і ті адміністративні договори, які майновими не є. Що стосується майнових адміністративних договорів, то ризикнемо припустити, що їхня управлінська мета є паралельною майновій, а отже, такий договір може бути одночасно ординарним адміністративним (викуп земельної ділянки для громадських і державних потреб у приватної особи) або господарським адміністративним (зобов'язання із дослідно-промислової експлуатації родовища корисних копалин), а отже, адміністративний характер договору не скасовує його місця у класифікації майнових договорів, а є лише ознакою відповідного майнового договору. Водночас немайновий адміністративний договір є родовим понятям, відмінним від майнових договорів взагалі.

\section{Jimepamypa}

1. Рєзніченко С.В. Еволюція договору як наслідок зміни суспільних відносин. Вісник ОНУ ім. І. І. Мечникова. Правознавство. 2016. Т. 21. Вип. 1 (28). С. 38-45.

2. Ільченко Г. Співвідношення понять «Цивільний договір» та «Господарський договір». Підприєлниuтво, господарство і право. 2017. № 2. С. 20-23

3. Цивільний кодекс України 16 січня 2003 р. № 435-IV. URL: https://zakon.rada.gov.ua/laws/show/ $435-15 /$ print.

4. Закон України «Про захист прав споживачів" від 12 травня 1991 р. № 1023-XII. URL: https://zakon.rada.gov.ua/laws/show/1023-12/print.

5. Господарський кодекс України від 16 січня 2003 p. № 436-IV. URL: https://zakon.rada.gov.ua/ laws/show/435-15/print.

6. Мельниченко Р.В. Обмеження договірної свободи сторін у цивільному праві України. Науковий вісник Ужгородського національного університету. 2015. № 30 . Ч. 1. С. $140-144$.

7. Гудима М.M. До питання про поняття предмета цивільного договору. Науковий вісник Ужгородського національного університету. Серія Право. 2013. Вип. 23. Ч. І. Т. 1. С. 182-186.
8. Кісель В.Й. Еволюція сутності цивільно-правового договору. Південноукраїнський правничий часопис. 2015. № 4. С. 69-74.

9. Гаврилішин А.П., Ошурко С.М. Загальні положення про господарські договори в Україні. Науковий вісник Ужгородського національного університету. Серія право. 2014. Вип. 24. Т. 2. С. 144-147.

10. Малишко В.М., Бородін Є.В. Поняття господарського договору: доктринальний аспект. Юридичний вісник. 2014. № 2 (31). С. 115-118.

11. Апаров А., Онищенко О. Юридична природа поняття господарського договору: Огляд наукових і нормативних підходів. Господарське право і проиес. 2016. № 10. С. $42-46$.

\section{Анотація}

Піддубний О. Ю. До питання про розмежування цивільних і господарських договорів і його вплив на інші види договорів. - Стаття.

Статтю присвячено традиційній проблемі розмежування цивільного та господарсько-правового договору і можливому впливу такого розмежування на розуміння місця інших видів договорів із погляду низки універсальних критеріїв.

Пропонується всі майнові договори поділити на три види - ординарний, споживчий і господарський. Враховуючи, що всі три види є цивільно-правовими у своїй основі, але споживчий і господарський договори відрізняються як між собою, так і щодо базового цивільного договору, запропоновано присвоїти йому типологічне найменування "ординарний» на противагу іншим двом, котрі мають свої особливості.

Як риса, яка є універсальною для всіх запропонованих видів, висувається їх майновий характер і визначається, що він є родовим. Іншою спільною рисою всіх майнових договорів є їхня цивільно-правова основа. Отже, всі означені договори є насамперед цивільно-правовими. Згідно з авторською класифікацією із застосуванням запропонованих критеріїв до цивільно-правових належать ординарний і споживчий договір, що існують як понятя одного порядку з господарським договором. Підтримується думка науковців, які стверджують, що господарський договір є також різновидом цивільно-правового договору, але має додаткову господарсько-правову специфіку.

Специфіка господарського договору вбачається автору у господарській діяльності й одночасно у її суб'єктах, для яких така діяльність є єдиною можливою.

Для розмежування ординарних і споживчих договорів, за авторським твердженням, неможливо обійтися без критерію предмету договору, а саме стандартизованого чи індивідуального товару або послуги. Також для споживчих договорів відзначається дисбаланс у правах і обов'язках сторін, що створює достатньо підстав, щоб розглядати такі договори як самостійне явище одного класифікаційного порядку з ординарним i господарським договорами.

Аналізується можливий вплив такої класифікації на місце трудового й адміністративного договору. Встановлено, що останній залежно від наявності чи відсутності майнового характеру може виступати як самостійне родове поняття або бути ознакою майнового договору.

Ключові слова: цивільний договір, господарський договір, ординарний договір, споживчий договір, адміністративний договір. 


\section{Summary}

Piddubnui $O$. Y. The question of the distinction between civil and commercial contracts and its impact on other types of contracts. - Article.

The article deals with the traditional problem of differentiating between civil and commercial law and the possible impact of such differentiation on the understanding of the place of other types of contracts in terms of a number of universal criteria.

It is proposed to divide all existing property contracts into three types - ordinary, consumer and economic. Given that all three types are civil in nature, but consumer and business contracts are different both in relation to the basic civil agreement, it is proposed to give it the typological name "ordinary" as opposed to the other two, which have their own peculiarities.

As a trait that is universal to all the proposed species, their property character is put forward and determined to be generic. Another common feature of all property contracts is their civil legal basis. Therefore, all of these contracts are first and foremost civil. According to the author's classification for the application of the proposed criteria to civil law are ordinary and consumer contract, which exist as concepts of the same order with the economic contract. This supports the view of scientists who claim that the economic agreement is also a type of civil contract, but has additional economic and legal specifics.

Specificity of the economic agreement is visible to the author in the economic activity and at the same time in its subjects for which such activity is the only possible one.

To distinguish ordinary and consumer contracts by copyright, it is impossible to do without the criterion of the object of the contract, namely, a standardized or individual product or service. Consumer contracts are also marked by an imbalance in the rights and obligations of the parties, which creates sufficient grounds to consider such contracts as an independent phenomenon of a single classification procedure with ordinary and business contracts.

The possible impact of this classification on the place of employment and administrative contract is analyzed. It is established that the latter, depending on the presence or absence of property character, can act as an independent generic concept, or be a sign of a property contract.

Key words: civil contract, economic agreement, ordinary contract, consumer agreement, administrative contract. 